Arhe XVI, 31/2019

UDK 11 Thomas Aquinas

DOI https://doi.org/10.19090/arhe.2019.31.15-33

Originalni naučni rad

Original Scientific Article

\author{
UNA POPOVIĆ ${ }^{1}$ \\ Univerzitet u Novom Sadu, Filozofski fakultet
}

\title{
UČENJE O TRANSCENDENTALIJAMA TOME AKVINSKOG: METAFIZIKA I SAZNANJE
}

Sažetak: Učenje o transcendentalijama Tome Akvinskog u ovom radu predstavljamo sa ciljem da ukažemo na njegovu imanentno saznajnu problematiku. Akvinčevo učenje biće analizirano s obzirom na pozadinski problem mogućnosti izgradnje transcendentalnih pojmova. Analiza rezultira naglašavanjem druge tri transcendentalije, kao ključa interpretacije celokupnog učenja, kao i isticanjem metafizičke, a ne teološke prirode problema transcendentalija. U konačnom, značaj učenja o transcendentalijama pokazuje se u svetlu izgradnje novog, tomističkog smisla metafizike.

Ključne reči: transcendentalije, Toma Akvinski, metafizika, saznanje, istina

Učenje o transcendentalijama predstavlja jednu od originalnih filozofskih doktrina srednjovekovlja, preciznije sholastičkog perioda. Iako svoje izvore ima još u Aristotelovoj metafizici, a posebno u Porfirijevoj (Porphyrios) interpretaciji Aristotelovih Kategorija, problem transcendentalija se $u$ vidu sistemski obrađene teme i centralnog impulsa metafizičkih istraživanja u punoj meri javlja tek u XIII veku, prevashodno kao izraz novog poimanja metafizike. Sholastička metafizika iskiva svoj osobeni karakter na pozadini učenja o transcendentalijama: on je pre svega određen upisivanjem problema saznanja $u$ metafiziku, odnosno problematizacijom mogućnosti izgradnje metafizike, čime se otvara horizont njene potonje novovekovne transformacije, oličene u Dekartovom (R. Descartes) učenju. Dodatno, povezivanjem metafizičke i saznajne

\footnotetext{
${ }^{1}$ E-mail adresa autorke: unapopovic@ff.uns.ac.rs
} 
perspektive sholastička misao posreduje i preoblikuje do tada najznačajniju filozofsku disciplinu srednjovekovlja, logiku (dijalektiku), potvrđujući je kao fundamentalni manir filozofskog mišljenja u ovom periodu, usmeren ne samo na formalne okvire istinitosti i valjanosti, već i na načelne probleme izrecivosti i pojmljivosti.

Učenje o transcendentalijama Tome Akvinskog ( $\mathrm{T}$. Aquinas) predstavlja jedan od zrelih oblika ovog učenja, po mnogo čemu reprezentativan za celokupnu epohu. Naime, čak i u onim aspektima učenja o transcendentalijama u kojima se Akvinski razlikuje od svojih savremenika, njegova misao pokazuje načelni smisao problema koji ovo učenje otelotvoruje za sholastičku misao, kao i širi horizont njegovih mogućih rešenja. Sa druge strane, s pravom se može reći da Akvinčevo učenje o transcendentalijama u malom predstavlja srž njegove metafizičke, pa i filozofske misli: sve što ono podrazumeva bitno određuje dalje okvire tomističke filozofije.

U redovima koji slede nastojaćemo da predstavimo učenje o transcendentalijama Tome Akvinskog, a naš centralni fokus i nit vodilja biće upravo transformacija metafizike koja mu stoji u osnovi i koja markira metafiziku kao scientia divina sholastičke misli. Fokusiraćemo se na klasični tekst De Veritate, koji prema našem mišljenju predstavlja okosnicu za razumevanje Akvinčevog učenja o transcendentalijama, inače prisutnog i u drugim tekstovima, pre svega u De Natura Genesis i Scriptum super Sententiarum. Većinom se u ovim tekstovima izlažu identični stavovi o transcendentalijama, no glavna razlika tiče se njihovog broja: dok su bonum, verum i ens prisutni u svim tekstovima, De Veritate tome dodaje aliquid i res. ${ }^{2}$ Navedeno pokazuje jasan uticaj arapske filozofije, a $\mathrm{s}$ obzirom na uže hrišćansko poreklo transcendentalija bonum i verum, odnosno s obzirom na kombinaciju dveju tradicija, smatramo da je spis $D e$ Veritate filozofski interesantniji i bogatiji posledicama.

\footnotetext{
${ }^{2}$ Up. Aertsen, A. J., Medieval Philosophy and the Transcendentals. The Case of Thomas Aquinas, Brill, Leiden, 1996, str. 102.
} 


\section{UČENJE O TRANSCENDENTALIJAMA: OSNOVNI OKVIR}

Pojam transcendentalija potiče od pojma transcendentalis, koji je nastao u XV-XVI veku, kao osobeno terminološko rešenje vezano za transformaciju pojma transcendens $\mathrm{u}$ sholastičkoj misli zrelog perioda. Konotacije ovih pojmova kasnije su bitno izmenjene Kantovim (I. Kant) radom, te stoga za savremenog istraživača u velikoj meri i neobične: umesto kantovske opozicije transcendentalnog i empirijskog, u slučaju srednjovekovlja transcendentalno je u opoziciji sa kategorijalnim i uopšte nije suprotstavljeno empirijskom - već je, naprotiv, intimno vezano za njega. ${ }^{3}$ Drugim rečima, srednjovekovne transcendentalije nisu čisti pojmovi uma, već pojmovi koji u svojoj izgradnji bitno zavise od čulnog zahvatanja stvarnosti.

Navedeno već samo po sebi ukazuje na aristotelovsko poreklo problema transcendentalija: naime, ovde je reč o najopštijim pojmovima kojima ljudski um barata, ali ipak o pojmovima koji moraju biti izgrađeni polazeći od uslova sveg saznanja - čulnog zahvatanja stvarnosti. Ipak, sam Aristotel nije ponudio razvijeno učenje o transcendentalijama: pojmove bića, istine i dobra - tri najčešća i najvažnija kandidata za transcendentalije - Aristotel, doduše, delimično analizira u duhu značajnom za potonji razvoj učenja o transcendentalijama, no njegov uticaj na ovu doktrinu pre je pitanje posrednog značaja Porfirijevih Isagoga, kao i Avicenine (Avicenna) metafizike, nego stvar direktne inspiracije Aristotelom. ${ }^{4}$

Najznačajniji impuls koji u ovom pogledu potiče od Aristotela je konstatacija, iznesena u IV knjizi Metafizike, da se istinito izriče mnogovrsno - kao i biće, odnosno kritika Platonovog univokalnog pojma dobra iz Nikomahove etike (1096a27-9), koja vodi ka mnogovrsnosti

\footnotetext{
${ }^{3}$ Up. Hall, A. W., 'Confused Univocality', u: G. Klima, A. W. Hall (eds.), Medieval Metaphysics, or is it 'Just Semantics', Cambridge Scholars Publishing, Cambridge, 2011, str. 36.

${ }^{4}$ Up. Bertolacci, A., 'Avicenna's and Averroes's Interpretations and Their Influence in Albertus Magnus', u: F. Amerini, G. Galluzzo (eds.), A Companion to the Latin Medieval Commentaries on Aristotle's Metaphysics, Brill, Leiden, 2014, str. 112.
} 
izricanja i ovog pojma. ${ }^{5}$ Aristotel tvrdi da pojmovi istine i bića imaju istu prirodu (physis), ali se ipak razlikuju pojmovno (logos). Savremenije rečeno, ovi pojmovi imaju različite konotativne sadržaje, ali su koekstenzivni; slično, onda, važi i za pojam dobro.

Najopštiji karakter transcendentalija na prvi pogled može da zavara i da ih postavi $u$ istu ravan kao i čuvene univerzalije, najviše rodove $u$ aristotelovskom smislu. ${ }^{6}$ Naime, i transcendentalije i kategorije su opšti pojmovi koji određuju unutrašnju strukturiranost našeg saznanja, ma o kom predmetu da je reč. Ipak, uprkos tome, ovi pojmovi nisu formalni, već su nerazdvojni od svoje semantike: kako smo videli, ključne razlike između više transcendentalija čine upravo njihove konotacije. Sa druge strane, iako posve opšti, ovi pojmovi se principijelno razlikuju - rečima Akvinskog, kategorije su pojmovi koji pripadaju mnogima, dok su transcendentalije pojmovi koji pripadaju svima. Njihovu razliku možemo razumeti kao razliku njihovih pojmovnih karaktera: u tom pogledu srednjovekovlje ce držati da transcendentalije izričito nisu kategorijalnog karaktera, odnosno da one prevazilaze kategorije tako što prožimaju svaku od njih. ${ }^{7}$ Pojam transcendentalis je, tako, oformljen kako bi se ovo trans-kategorijalno značenje i terminološki razdvojilo od pojma transcendens i njegove izvorne konotacije, koja upućuje na dostojanstvenost predmeta koji se njim označava.

${ }^{5}$ Up. MacDonald, S., Being and Goodness: The Concept of the Good in Metaphysics and Philosophical Theology, Ithaca, Cornell University Press, 1991, str. 57.

${ }^{6}$ Boetije zacrtava razumevanje univerzalija vezujući ovaj pojam za pitanje da li rodovi i vrste postoje realno; u ranoj srednjovekovnoj misli i aristotelovskoporfirijevske predikabilije su bile poznate kao univerzalije, usled toga što se pod univerzalijama podrazumevalo ono što se može predicirati mnogima.

${ }^{7}$ Za razliku od ovog najčešće usvojenog stanovišta, Duns Skot (Duns Scotus) smatra da domen predikabilija (univerzalija) treba proširiti transcendentalijama. Tako će pet osnovnih predikabilija, usvojenih od Porfirija - rod, vrsta, razlika, svojstvo i akcidencija - u Skotovoj misli biti dopunjene šestim tipom, universale transcendens. Up. Aertsen, J., Medieval Philosophy as Transcendental Thought: From Philip the Chancellor (ca. 1225) to Francisco Suárez, Brill, Leiden, 2012, str. 19. 
Transcendentalije su, tako, najopštiji pojmovi - opštiji čak i od kategorija, u punom smislu communissime, zajednički. Ipak, opštost transcendentalija i opštost kategorija nije ista opštost: dok je kategorijalna opštost oličena u odnosu roda i vrste, te tako najviši rodovi predstavljaju univerzalije, za transcendentalije takav odnos ne važi; samim tim, transcendentalije nisu univerzalije. ${ }^{8}$ Razlog tome počiva na centralnom od svih transcendentalnih pojmova, pojmu biće (ens). Kako je dobro poznato, već Aristotel tvrdi da biće nije rod; ovo tvrđenje u punom smislu predstavlja okosnicu srednjovekovnog učenja o transcendentalijama i zacrtava njegove okvire.

Ipak, kada govorimo o srednjovekovlju, moramo imati na umu da pojam bića u ovom kontekstu sasvim odstupa od Aristotelovog pojma, te se stoga celokupna rasprava postavlja na bitno hrišćanske osnove. Ovde pre svega mislimo na osnovni diktum srednjovekovne metafizike - esse (odnosno ens) preuzima primat u odnosu na essentia, ono da jeste je značajnije od šta jeste. Pojam biće, tako, otkriva pravi smisao učenja o transcendentalijama: reč je, naime, o osnovnom problemu hrišćanske metafizike - problemu poimanja odnosa između stvorenja i Boga, odnosno problemu održavanja razlike između ta dva relata, uprkos doktrinarnoj uslovljenosti da se oni misle u svojoj povezanosti, oličenoj u otkrivenoj istini da je Bog stvorio svet.

Učenje o transcendentalijama, tako, nastupa kao teorijski pokušaj da se razreši pitanje ovog esse, u datom slučaju u nešto konkretnijem obliku, ens. U ovom okviru transcendentalni pojam figurira kao pojam posebnog tipa, pri čemu će transcendentalije $\mathrm{u}$ svakom pogledu biti nadređene kategorijama: do transcendentalija, dakle, dolazimo kada zakoračimo dalje u odnosu na kategorije, a s obzirom na ono što je za sve njih zajedničko, što važi za sve njih. Reč je o tome da svaka od kategorija, pored onog što specifično naznačava, istovremeno posreduje i svest o jeste; primera radi, ukoliko razmatramo neki kvalitet, recimo žuto, taj kvalitet uvek i bez izuzetka zahvatamo kao nešto što jeste, makar i na način postojanja u razumu. Drugim rečima, ovakav nalaz ukazuje na misaoni

\footnotetext{
${ }^{8}$ Up. Gracia, J. J. E., 'Categories vs. Genera: Suarez's Difficult Balancing Act', u: Medieval Metaphysics, or is it 'Just Semantics', str. 11.
} 
sadržaj koji prožima sve kategorije iznutra, te imanentno upućuje preko kategorija, ka nečemu sasvim drugačijem od njih: za to nešto, međutim, već posedujemo pojam - esse, ens - te utoliko taj pojam možemo podvrgnuti filozofskoj analizi.

Filozofska analiza ovog pojma, međutim, predstavlja naročit izazov. S obzirom na prethodno rečeno, jasno je da se radi o pojmu koji predstavlja krajnji horizont pojmovnog - ali i saznajnog - dometa ljudskog uma. Stoga, budući da je u pitanju sama granica poimanja i pojmovlja, njegov karakter mora imati sasvim osobene odlike, koje prevazilaze ono što se o transcendentalijama može naučiti s obzirom na kategorije. U konkretnom, reč je upravo o vezi pojmljivosti i pojmovlja, odnosno o vezi mogućnosti (sa)znanja i pojmovnosti kao unutrašnjeg načina operisanja razuma, inteligibilnosti kao saznajne sposobnosti. Navedeno je oličeno u stavovima Avicene: u specifičnom „epistemičkom” zaokretu, Avicena će uvesti tezu o prvim pojmovima uma - o pojmovima koji se ne mogu definisati drugim pojmovima i saznati na taj način. Naprotiv, sa prvim pojmovima radi se o pojmovima koji u većoj ili manjoj meri određuju poimanje i/ili definisanje svih ostalih pojmova. Zauzvrat, oni sami ne mogu biti pojašnjeni međupojmovnim odnosima, već se znaju „po sebi”; njihov smisao je po sebi očigledan. ${ }^{9}$ Nešto jednostavnije rečeno, ovi pojmovi zaobilaze odnose roda, vrste i razlike, koji sačinjavaju strukturu definicije.

Ipak, iako su u pitanju prvi pojmovi, oni nisu nama neposredno jasni i vidljivi, niti se radi o čistim ili urođenim pojmovima razuma. Ukoliko treba da otkrijemo ono što leži u osnovi svekolikog znanja, mi se najpre moramo probiti kroz konkretne primere znanja i saznavanja, te njihovom analizom ustanoviti ono što ih unapred određuje. To, međutim, ne znači da su u pitanju strogo empirijski pojmovi: oni ne govore primarno o onome što se u spoljašnjoj stvarnosti saznaje, već svedoče o onome što je uvek na delu kada se odvija saznavanje nečeg spoljašnjeg. Nešto slobodnije rečeno, ovi pojmovi svedoče o uslovima mogućnosti sticanja znanja: o

\footnotetext{
${ }^{9}$ Up. Aertsen, J., 'Why is Metaphysics Called 'First Philosophy' in the Middle Ages', u: G. T. Doolan (ed.), The Science of Being as Being. Metaphysical Investigation, The Catholic University of America Press, Washington, 2012, str. 59-60.
} 
onome što mora biti mišljeno kada se barata sa pojmovima i pojmovnim odnosima, unutrašnjim tkivom svakog znanja.

Navedeno predstavlja pozadinski horizont i Akvinčevog učenja o transcendentalijama: kako je već navedeno, Akvinski crpi kako iz hrišćanske, tako i iz arapske tradicije, te je stoga njegova pozicija istovremeno i sistematična i inovativna. Iznova, kao takva, ona se najbolje pokazuje u spisu De Veritate, čijoj se analizi nadalje posvećujemo.

\section{UČENJE O TRANSCENDENTALIJAMA TOME AKVINSKOG}

Akvinski transcendentalijama pristupa posve $\mathrm{u}$ duhu prethodno ocrtanih ideja: transcendentalije su za njega suprotstavljene i nadređene kategorijama, te predstavljaju prve pojmove ljudskog intelekta, najpoznatije i najspoznatljivije okvire stvarnosti. U tom pogledu Akvinski se, očigledno, oslanja na Avicenu; međutim, Avicenini impulsi će u slučaju Akvinskog zadobiti sasvim nov oblik.

U klasičnom tekstu De veritate (pitanje 1, odgovor 1) Akvinski izdvaja pet transcendentalija: jedno (unum), stvar (res), drugo/nešto (aliquid), istinito (verum) i dobro (bonum); pored ovih pet transcendentalija postoji još jedna - biće (ens) - kao prva od njih i ona na koju sve ostale upućuju. ${ }^{10}$ Ovde je, dakle, reč o pojmovima koji su koekstenzivni pojmu ens, te koji sa njim stoje u posve specifičnom odnosu: prema Akvinskom, konotacije navedenih pojmova predstavljaju zapravo imanentni sadržaj pojma biće, sadržaj koji je dat zajedno sa njim i koji uvek zahvatamo kada zahvatamo pojam bića, ali takođe i sadržaj koji samim pojmom biće nije razvijen - a samim tim ni vidljiv. ${ }^{11}$ Navedeno govori pre o mogućnostima da mi razumemo ens i esse, nego o samim ens i esse, ontološki gledano: naime, iako baratamo ovim pojmovima, naš razum nije u stanju da u celosti i odjednom razume njihov smisao, te je taj smisao stoga razvijen $u$ nekoliko dodatnih transcendentalnih pojmova.

${ }^{10}$ Up. St. Thomas Aquinas, Questiones Disputatae De Veritate, Vol. I, Henry Regnery Company, Chicago, 1952, str. 1-7.

${ }^{11}$ Up. Isto, str. 3. 
Prateći Avicenu, Akvinski pristupa analizi transcendentalnih pojmova oslanjajući se na logiku: tako je prva razlika koju on uspostavlja između transcendentalija razlika u pogledu na subjekt kome se prediciraju ovi pojmovi. Razlog tome je način na koji funkcioniše naš razum - ukoliko već poseduje pojmove, ma kakvi oni bili, jedino što razum sa njima može da uradi jeste da uspostavlja međupojmovne veze, a one su, pak, fundamentalno oličene $\mathrm{u}$ iskazima (veritas logica). ${ }^{12}$ Shodno tome, Akvinski iskaznu formu uzima kao kriterijum razlikovanja između transcendentalija. ${ }^{13}$ Sa druge strane, iskazna forma podrazumeva predikaciju, odnosno pripisivanje predikata subjektu: u ovom slučaju, fundamentalni subjekt je samo ens, te se stoga ostale transcendentalije posmatraju kao njegovi predikati. ${ }^{14}$ Otuda, Akvinčev kriterijum ovde je zapravo pitanje kako se načelno može govoriti o biću, a rešenje koje on nudi je dvostruko: o biću se može govoriti s obzirom na njega samog, ili $s$ obzirom na druga bića. ${ }^{15}$

U prvom slučaju reč je, očigledno, o relaciji identiteta, te tako projekat transcendentalija započinje kao logički prelaz od jednog termina (ens) na mogućnost povezivanja tog termina sa samim sobom - „S je S”. Prateći formu iskaza kao pozadinu kriterijuma razvijanja transcendentalija, Akvinski u tom smislu zaključuje: u pogledu na samo sebe, biće se može izreći ili afirmativno, ili negativno; veza sa strukturom iskaza očigledna je, pošto je ovde reč o određenju iskaza prema kvalitetu.

Jednostavnije rečeno, ukoliko se biće spram sebe potvrđuje, ono se prema Akvinskom izriče kao stvar (res); ukoliko se ono spram sebe odriče, onda se ono izriče kao jedno (unum). ${ }^{16}$ Donekle neobičan zaključak

${ }^{12}$ Up. Elders, L. J., The Metaphysics of Being of St. Thomas Aquinas in a Historical Perspective, Brill, Leiden, 1993, str. 110.

${ }^{13}$ Navedeno je vezano za činjenicu da je i učenje o transcendentalijama vid saznanja, odnosno podložno smislu i okvirima istinitosti. Up. St. Thomas Aquinas, Questiones Disputatae De Veritate, Vol. I, str. 11.

$14 \mathrm{U}$ tom smislu Akvinski uvodi i semantičku hijerarhiju između transcendentalija. Up. St. Thomas Aquinas, Questiones Disputatae De Veritate, Vol. III, Henry Regnery Company, Chicago, 1954, str. 11.

${ }^{15}$ Up. St. Thomas Aquinas, Questiones Disputatae De Veritate, Vol. I, str. 3-4.

${ }^{16}$ Up. Isto, str. 4. 
zapravo podrazumeva sledeće: potvrđivanje bića u ovom pogledu znači njegovo izricanje kao nekog bića, što zapravo znači njegovo dalje određenje u svetlu štastva - biće koje jeste uvek je nekakvo i neko konkretno biće, imanentno određeno sopstvenom suštinom. ${ }^{17}$ Sa druge strane, ukoliko se biće spram sebe odriče, to ne znači da se ono poništava, već da se određuje kao nedeljivo - odnosno kao jedno: u ovom pogledu Akvinski prati Aristotelovo određenje smisla pojma jednog iz X knjige Metafizike. ${ }^{18}$ Drugim rečima, ukoliko govorimo o biću, uvek podrazumevamo da je u pitanju jedno biće, odnosno da je u pitanju nekakvo biće: ove dve trancendentalije po funkciji odgovaraju pojmovima supstantia (jedno) i essentia (nekakvo, neko) s obzirom na esse.

Druga mogućnost za Akvinskog je da se biće izriče spram drugih bića. U tom slučaju iznova imamo varijante afirmacije i negacije, no one se ovaj put ne imenuju tako, jer nije reč o odnosu spram jednog, već o odnosu između više bića. Postavljen u kontekst između više supstancija, princip negacije pokazuje se kao njihovo razlikovanje, nesvodivost jedne na drugu, što Akvinski označava pojmom nešto/drugo (aliquid). ${ }^{19}$

Jednostavnije rečeno, ukoliko govorimo o odnosu između više bića, prvo što se u tom smislu pokazuje je upravo činjenica da ih ima više, odnosno da jedno biće jeste upravo to - a ne neko drugo biće. ${ }^{20} \mathrm{U}$ tom smislu je transcendentalija aliquid po funkciji slična transcendentaliji unum, iako one o biću govore u dva različita konteksta. Različiti konteksti su, međutim, vidljivi na nivou karaktera iskazivanja: naime, ukoliko smo u slučaju res i unum imali osnovni iskaz identiteta, „S je S”, sada to ne može biti slučaj, jer je na delu upravo uvid u to da jedno $\mathrm{S}$ (biće, supstancija) nije isto što i drugo $\mathrm{S}$ (biće, supstancija). Ovom odnosu primerenije je pripisati

${ }^{17}$ Veza res i essentia, stvari i suštine, naglašena je kod Avicene, koga Akvinski ovde očigledno prati; Avicena je prvi koji razlikuje ens i res, te određuje res kao indeks suštine bića ukoliko je dostupna saznanju. Up. Elders, L. J., The Metaphysics of Being of St. Thomas Aquinas in a Historical Perspective, str. 78, 81.

${ }^{18}$ Up. Isto, str. 89.

${ }^{19}$ Up. St. Thomas Aquinas, Questiones Disputatae De Veritate, Vol. I, str. 4.

${ }^{20}$ Up. Wippel, J. F., Metaphysical Themes in Thomas Aquinas II, The Catholic University of America Press, Washington, D.C., 2007, str. 77. 
iskaz relacione forme, „S r S”, pri čemu bi relacija izricala višestrukost i bogatstvo mogućih „biti u odnosu” između različitih supstancija - na primer: „Mačka juri miša”, „Knjiga je na stolu” i slično.

$\mathrm{U}$ istom kontekstu afirmacija bi, onda, trebalo da se pokaže kao međusobna sličnost, slaganje više supstancija - ali nikako kao njihov identitet, jer ovde na delu imamo i numeričko i realno razlikovanje više bića, budući da dva različita bića ne mogu da budu jedno. Dodatno, nemogućnost identiteta u ovom pogledu ograničena je samo na odnos između dva bića, o kome svedoče tri transcendentalije - identitet je i dalje na delu u okviru kategorijalne shematike, budući da svaka od kategorija upućuje na supstanciju ne samo u smislu predikacije, već i u smislu sopstvenog „,biti”.

Jednostavnije rečeno, u slučaju prve dve transcendentalije, res i unum, kao i kod kategorijalnih shemata, identitet je jasno vidljiv, iako dat na različite načine; ovde se radi o autoreferencijalnim kontekstima. Budući da su transcendentalije nadređene kategorijama, jasno je $\mathrm{i}$ da je „transcendentalni” smisao identiteta (S je S) u osnovi „kategorijalnog” smisla identiteta ( $\mathrm{S}$ je $\mathrm{P}$ ), čime se predikacija pokazuje kao identitet u sekundarnom smislu. Ipak, iako nije vidljiv na prvi pogled, identitet je kao fundamentalni princip prisutan i u slučaju druge tri transcendentalije aliquid, verum i bonum. ${ }^{21}$ On se kao takav razotkriva najpre s obzirom na činjenicu da su sve transcendentalije zapravo u odnosu eksplikacije spram one prve, ens - one izražavaju samo biti na različite načine. Sa druge strane, odnosi između više bića, za koje smo prethodno rekli da im je primerenija forma relacionog iskaza, identitet onog biti artikulišu ne u pogledu identiteta jednog bića spram drugog, već spram onog izvornog biti od koga sva bića potiču i spram kog u konačnom i jesu bića. U ontološkom smislu to je esse samog Boga, što Akvinski razvija učenjem o analogia entis.

Ipak, razlika u pogledu forme iskaza primerene autoreferencijalnim kontekstima (identitet) i primerene izražavanju odnosa između bića - što se u slučaju učenja o analogia entis artikuliše preko forme

${ }^{21}$ Akvinski ovo naznačava s obzirom na pojam istinito. Up. St. Thomas Aquinas, Questiones Disputatae De Veritate, Vol. I, str. 9. 
analogije, a u slučaju transcendentalija pokazuje kao relaciono mišljenje ima svoj dublji smisao. ${ }^{22}$ Naime, ona služi jasnom i formalnom razlikovanju bića koja su stvorena i božanskog bića. Strategija Akvinskog se oslanja na Aristotela: naime, prema Akvinskom, svi naši pojmovi izvedeni su iz susreta sa stvorenim bićima; isto onda važi i za transcendentalije, odnosno za ens/esse. Posledično, pojam esselens ne može da se odnosi na Boga jer nije zadobijen na osnovu bilo kakvog susreta sa njim, iako može posredno da se primeni na njega; to je ens/esse stvorenih bića, metafizički pojam bivstvovanja/bića. ${ }^{23} \mathrm{U}$ ovom pogledu Akvinski ide direktno protiv Avicene.

Stoga, da je pojam ens primenljiv i na Boga, odnosno zadobijen nekakvim isključivim uvidom u božansko biće, Akvinski bi morao da se zadrži na prve dve transcendentalije, res i unum. Unum bi, tako, označilo da je Bog jedan, dok bi res u slučaju Boga uputilo ne na essentia, već na realitas, actualitas - na činjenicu da Bog jeste. Međutim, pošto je ovaj pojam izveden polazeći od stvorenja, on se mora izricati i eksplicirati i tako da ukaže na svoje poreklo - $\mathrm{u}$ tom smislu Akvinski uvodi druge tri transcendentalije. Celokupan Akvinčev projekat transcendentalija vidi se jasno upravo u kontekstu ovih tri koje izriču odnose između bića: navedeno je posebno jasno u slučaju afirmacije odnosa između više bića.

U tom pogledu Akvinski pravi neobičan zakoret, te tvrdi da se duša na neki način slaže sa svim, odnosno da duša svim bićima korespondira. Potom, imajući u vidu da duša ima dve primarne funkcije - razumevanje i apeticiju - Akvinski spram njih izdvaja istinito (verum), odnosno dobro (bonum), kao dodatne dve transcendentalije. ${ }^{24}$ Vredi primetiti da je dobro ovde neposredno i izričito vezano za ljudsku dušu - a ne za samog Boga, kao što je to bio slučaj u početnim fazama učenja o transcendentalijama (transcendens u značenju dostojanstva). ${ }^{25}$

\footnotetext{
${ }^{22}$ Up. Gilson, E., Thomism. The Philosophy of Thomas Aquinas, Pontifical Institute of Mediaeval Studies, Toronto, 2002, str. 409-410.

${ }^{23}$ Ukoliko se pojam esse posredno primeni na Boga, onda u tom slučaju važe $\mathrm{i}$ svi odnosi ens/esse i drugih transcendentalija. Up. Isto, str. 105.

${ }^{24}$ Up. St. Thomas Aquinas, Questiones Disputatae De Veritate, Vol. I, str. 4.

${ }^{25}$ Up. Wippel, J. F., Metaphysical Themes in Thomas Aquinas II, str. 226.
} 
Uvođenje duše u izgradnju i pojašnjenje unutrašnje logike u odnosima između transcendentalija, čini se, ukazuje na ključ za razumevanje Akvinčeve podele. Transcendentalije su, naime, pojmovi - i to pojmovi koji moraju biti izgrađeni analizom drugih pojmova, iako su na delu prvi. Činjenica da ovi pojmovi za srednjovekovne mislioce ukazuju na realna svojstva realnih bića ne menja na stvari, jer je centralno pitanje učenja o transcendentalijama način na koji su bića nama data za saznanje. Jednostavnije rečeno, iako sve transcendentalije ukazuju na realno postojeća svojstva realno postojećih bića, za saznanje ta svojstva data su kao predikati osobene vrste, kao transcendentalni pojmovi - a budući pojmovi, oni pripadaju duši i izgrađeni su radom razuma. To pokazuju poslednje dve transcendentalije: ljudska duša je u saglasju sa svim stvarima utoliko što ona može da sazna bilo koju od stvorenih stvari. ${ }^{26}$ Ipak, u odnosu na forme drugih bića duša se može postaviti uže saznajno, usled čega se biće razume kao istinito - ili shodno svom apetitivnom aspektu, usled čega za nju biće važi kao neko dobro, čemu duša može da teži. Biće stvari se, dakle, za dušu pokazuje kao ono što ona pokušava da sazna, ili kao ono ka čemu se ona orijentiše.

Činjenica da je duša postavljena kao dodatni aspekt diferenciranja transcendentalija u navedenom kontekstu, prema našem mišljenju, ukazuje na to da sve transcendentalije svedoče nešto o samoj duši, o njenom pozicioniranju spram bića. Iako je navedeno istaknuto samo za slučaj poslednje dve transcendentalije, verum i bonum, prethodne analize dovoljno pokazuju da je isto na delu i kod preostalih. Reč je, dakle, o pojmovima koji u najvećoj mogućoj meri svedoče o onome kako mi zahvatamo stvarnost, polazeći od same stvarnosti i načina na koji smo, shodno svojim saznajnim mogućnostima, u stanju da je pojmimo. Istovremeno, kod Akvinskog je jasno naglašeno da naše saznanje ne može da dosegne do Boga. ${ }^{27}$ Ovaj stav upisan je u njegov metafizički projekat, a time je i saznajna problematika u njega upisana: u tom smislu, zadatak metafizike - da pojasni ono esse - razotkriva se kao zadatak da se položi

\footnotetext{
${ }^{26}$ Up. Isto, str. 93.

27 Up. Elders, L. J., The Metaphysics of Being of St. Thomas Aquinas in a Historical Perspective, str. 107.
} 
račun o pojmovima kojima se esse u našem razumu eksplicira i posredno saznaje. Konačno, pošto su transcendentalni pojmovi u tom pogledu najtemeljniji, uži zadatak metafizike je da rasvetli njihove međusobne odnose, to jest odnose ostalih transcendentalija prema onom ens.

Razlikovanje transcendentalija kod Akvinskog, odnosno karakter njihovog odnosa prema biću, prati dotadašnju tradiciju: kako je uobičajeno, Akvinski odnose transcendentalija prema pojmu bića razume kao odnose tipa supstancija-svojstvo. Iako je prethodno bilo reči o primatu identiteta, a ne predikacije, to ovde ne treba da zbuni: kako smo videli, predikacija u svom imanentnom smislu jeste oblik identiteta, $i$ to onaj sa kojim se $u$ našem mišljenju ponajpre susrećemo. ${ }^{28}$ Akvinski ovde samo stvar posmatra polazeći od načina na koji intellectus duše funkcioniše najčešće i uglavnom; s obzirom na to, možemo očekivati da se neki od oblika predikacije pokaže kao uputan u pogledu odnosa između transcendentalija. Da je u pitanju predikacija nekategorijalnog - transcendentalnog - tipa predikata videli smo već prema razlikovanju transcendentalija i kategorija: sada je, međutim, reč o tome da se odredi koji je oblik predikacije odgovarajući takvim neobičnim predikatima.

Da nije reč o predikaciji akcidencija, čini se jasnim samo po sebi; slično važi i za odnose rod/vrsta/razlika, koji ulaze u definicije transcendentalije se, međutim, ne mogu definisati, jer su u pitanju prvi pojmovi, a i dodatno - biće nije rod. Stoga ostaje samo mogućnost da je predikacija transcendentalija izvedena po modelu prediciranja svojstva: budući da svojstvo podrazumeva predikat koji nije deo definicije neke stvari, a ipak joj bitno pripada, ovaj model se čini sasvim prirodnim kandidatom za oblik predikacije transcendentalija. Ovim, međutim, nije rečeno da transcendentalije predstavljaju jednu od univerzalija, niti da se one podređuju kategorijalnoj shemi pojmovnih odnosa. Naprotiv, time je rečeno samo to da odnos koji je u slučaju supstancije i onog što joj se pripisuje izražen modelom predikacije svojstava odgovara načinu na koji se pojmovno uspostavlja odnos između pojma bića i ostalih transcendentalija.

\footnotetext{
${ }^{28}$ Up. Aertsen, A. J., Medieval Philosophy and the Transcendentals. The Case of Thomas Aquinas, str. 96-97.
} 
Navedeno ne treba da čudi: budući da je esse izvorni smisao postojanja, pa utoliko i svih raznolikih načina na koje se postojanje zahvata, razlikuje i razumeva, onda se upravo preko pojma esse mora razumeti i bilo koji način povezivanja više različitih zahvatanja postojanja. Drugim rečima: predikativni iskaz povezuje određeni subjekat supstanciju - sa određenim predikatom - svojstvom, tvrdeći (ili odričući) da ova dva pojma upućuju na isto realno biće (teorija supozicije). Gledano iz obrnute perspektive: neko realno biće može se u svom postojanju zahvatiti kao nekakvo, u kom slučaju je zahvaćeno i ,jeste” pojedinačnog bića (supstancija) i ,jeste" njegovog svojstva (predikat), i to kao međusobno pripadnih; njihova pripadnost se $u$ formalnom smislu izražava kopulom, koja ustanovljava da dva termina upućuju na isto realno biće, iako u kategorijalnom smislu pokazuju ,jeste” tog bića na različite načine.

Jednostavnije rečeno, ono što predikacija - pripisivanje predikata subjektu - izražava zapravo nije predikacija, već identitet; dodatno, taj identitet nije identitet različitih realnih bića, već identitet kategorijalno različito zahvaćenih načina bivstvovanja nekog realnog bića, identitet različito zahvaćenog esse tog bića. Stoga, ukoliko je esse stožerno mesto bilo koje predikacije i identiteta, kako u semantičkom, tako i u formalnosintaksičkom smislu, onda se mogućnost da se odnosi transcendentalija razumeju preko modela predikacije svojstva ne upostavlja s obzirom na univerzalije i predikabilije $u$ osnovnom smislu, već imanentno s obzirom na transcendentalije. Logički gledano, transcendentalije imaju primat: model pojmovnih odnosa koji važi među njima upisan je u sve druge pojmovne odnose, te je u tom smislu model predikacije svojstva posledica načina predikacije transcendentalija, a ne obrnuto. ${ }^{29}$

Kako smo videli, način na koji Akvinski razume ove odnose je eksplikacija, razvijanje smisla onog ens/esse na različite formalno određene načine, čime se dobijaju transcendentalije. Imajući u vidu prethodno, možemo reći da je pravi smisao svih transcendentalija upravo esselens, odnosno da one izriču biće/bivstvovanje neposredno, ali ipak u određenom aspektu. Shodno tome, i kategorijalna shematika, koja počiva na transcendentalnoj, mora izricati isto to, upravo biće/bivstvovanje, no sada

\footnotetext{
${ }^{29}$ Up. St. Thomas Aquinas, Questiones Disputatae De Veritate, Vol. I, str. 8.
} 
na način ograničavanja njegovog smisla u pogledu onoga kako jedno pojedinačno biće jeste. U konačnom, zaključak je da je svekoliko izricanje i saznanje zapravo izricanje i saznanje bivstvovanja pojedinačnih stvorenih bića, te da se, usled činjenice da takvih bića ima nepregledno mnogo, biće zaista izriče mnogovrsno. Učenje o kategorijama, učenje o transcendentalijama, te konačno analogia entis u filozofiji Tome Akvinskog predstavljaju različite strategije opkoljavanja tog mnogovrsnog izricanja, te za cilj imaju polaganje računa o njegovim okvirima.

\section{ZAKLJUČNA RAZMATRANJA}

Ključni aspekt Akvinčevog razmatranja transcendentalija, ipak, nije njihova podela, niti njihovi odnosi - reč je o preuzimanju Avicenine ideje da se radi po prvim pojmovima uma. Kao prvi pojmovi, transcendentalije zapravo predstavljaju specifičan, skoro formalni opis imanentnog operisanja razuma. Jednostavnije rečeno, budući da je ljudska duša prema Akvinskom anima rationis, te je stoga upotreba razuma odlikovani način postojanja čovekom, pitanje saznanja i znanja imaju ovde izuzetno važno mesto. Dodatno, iako je proces sticanja znanja za Akvinskog nužno vezan za čulno opažanje, samo znanje realizuje se u domenu pojmovnosti i predstavlja posledicu rada razuma u užem smislu. Rad razuma, međutim, određen je onim što Akvinski zove pravim objektima saznanja: reč je o tome da je svaka saznajna sposobnost usmerena na pojedinačna bića koja zahvata na tačno određen i međusobno nesvodiv način. Primarni objekti saznanja za određenu saznajnu sposobnost, onda, predstavljaju ono što je u njenom okviru najpre $\mathrm{i}$ najadekvatnije saznatljivo. U slučaju razuma, međutim, Akvinski tvrdi da su pravi objekti saznanja upravo prvi pojmovi uma, transcendentalije: posledično, to podrazumeva da su transcendentalije ne samo uvek nekako saznate i samim tim najsaznatjivije, već i da one pokazuju same granice razumskog saznanja.

Nešto slobodnije bismo mogli reći da su u pitanju pojmovne forme, pojmovne matrice koje unapred određuju način zahvatanja stvarnosti u celini i u svakom konkretnom slučaju, ukoliko se radi o inteligibilnom zahvatanju stvarnosti. Ovo skoro kantovsko tvrđenje se, 
ipak, mora sasvim precizno razumeti, kako se ne bi pomešalo sa Kantovim: ovde nije reč o pojmovnim matricama koje a priori određuju način zahvatanja stvarnosti, već su u pitanju pojmovne matrice koje nastaju na osnovu već ostvarenog zahvatanja stvarnosti empirijskim putem. U tom smislu transcendentalije nisu puki pojmovi, već pojmovi koji ukazuju na realne odlike stvarnosti - jednako kao što metafizika još uvek predstavlja jednu realnu nauku (scientia realis). Ipak, ma koliko da one ukazivale na realna svojstva stvari i na konstituciju realnosti uopšte, transcendentalije istovremeno ukazuju i na okvire pod kojima racionalna duša zahvata takvu realnost. ${ }^{30}$ Drugim rečima, iako se ovde pretpostavlja homologija strukture realnosti i strukture saznanja te realnosti - u meri u kojoj je ona saznata i može biti saznata, ta pretpostavka za Akvinskog ipak ne ukida potrebu da se odnos dve strukture ispita, te da se struktura saznanja podvrgne filozofskoj analizi. ${ }^{31}$

Navedeno rezultira $\mathrm{u}$ vrlo specifičnom gestu upisivanja epistemičke perspektive u izgradnju metafizike, te povezivanjem problema saznanja i ontološkog aspekta stvarnosti na skoro neraskidiv način. Naime, iako rečeno zvuči kao posve novovekovni, dekartovki gest, on to ipak nije u jednom važnom pogledu: Akvinčevo razumevanje metafizičke strukture stvarnosti ne zavisi od njegovih saznajnih moći - štaviše, ovu strukturu on poznaje iz natprirodnih, milošću darovanih izvora. Samo s obzirom na Otkrovenje, naime, Akvinski i mi zajedno sa njim znamo da pored materijalnih bića postoje i anđeli, kao i Bog, te da je svet materijalnih bića, inače dostupan našim prirodnim saznajnim sposobnostima bez ostatka, zapravo jedan stvoreni svet.

Drugim rečima, za Akvinskog metafizika ne može predstavljati projekat istraživanja i otkrivanja osnova realnosti, budući da je sa njima on već unapred upoznat. Umesto toga, metafizika može biti samo ispitivanje granica do kojih prirodne razumske sposobnosti čoveka mogu dopreti u tom pogledu, pri čemu otkrivena struktura stvarnosti predstavlja kriterijum uspostavljanja tih granica. Štaviše, pitanje za Akvinskog onda više i nije šta

\footnotetext{
${ }^{30}$ Up. Isto, str. 5, 7-8.

${ }^{31}$ Aertsen, A. J., Medieval Philosophy and the Transcendentals. The Case of Thomas Aquinas, str. 79.
} 
čini realnost u njenoj strukturi, već je pitanje inverzno - šta čini metafiziku kao nauku, koji su uslovi mogućnosti da ona bude jedna od nauka (scientia)? Ovo pitanje vodilo je Avicenin pristup čitanja Metafizike polazeći od Druge analitike; kada je reč o Akvinskom, pitanje zadobija nešto drugačiji smisao, jer Akvinski ne prilazi problemu izgradnje i legitimnosti metafizike polazeći od njenog naučnog karaktera, već polazeći od ispitivanja horizonta značenja - semantičkog horizonta - koji je dostupan za izgradnju metafizike.

Stoga, Akvinski projektu metafizike pristupa polazeći od pitanja o domašaju naših saznajnih moći: ukoliko je proces saznanja uvek iniciran čulnim opažanjem, isto mora da važi i za metafizičko znanje - i metafizički pojmovi, više ili manje očigledno, moraju da upućuju na empirijski zahvaćena realna bića i da otuda crpu svoj smisao. ${ }^{32}$ Ukoliko se stvar postavi tako, Akvinski ne može, poput Avicene, da tvrdi da subiectum metafizike - biće kao biće (ens inqua est ens) - obuhvata i Boga, iako Boga smatra jednim od realno postojećih bića. On to ne može ne zbog toga što Bog nije jedno od bića, jedna od supstancija, već zbog toga što je pojam bića sa kojim on sam barata izgrađen polazeći od zahvatanja bića koja nisu Bog, već stvorenja, odnosno zbog toga što Boga nikada nije imao priliku da opazi.

U ovakvom projektu metafizike učenje o transcendentalijama predstavlja kamen-temeljac, no ipak je u pitanju temelj koji tek treba razotkriti. Učenje o transcendentalijama, međutim, zadobija takvu funkciju ne samo s obzirom na tezu da su transcendentalije prvi pojmovi, same granice poimanja stvarnosti, već i u pogledu toga da se ovde radi o učenju, o specifičnoj teoriji. Drugim rečima, pod znakom pitanja ovde stoji i sama mogućnost znanja o transcendentalijama; na ovaj problem Akvinski, kako smo videli, odgovara direktnim povezivanjem njihovog metafizičkog i epistemičkog karaktera. Time se, smatramo, potvrđuje teza o druge tri transcendentalije (aliquid, verum, bonum) kao ključu interpretacije celokupnog učenja o transcendentalijama.

${ }^{32}$ Up. St. Thomas Aquinas, Questiones Disputatae De Veritate, Vol. I, str. 8-9. 


\section{LITERATURA}

Aertsen, A. J., Medieval Philosophy and the Transcendentals. The Case of Thomas Aquinas, Brill, Leiden, 1996.

Aertsen, J., Medieval Philosophy as Transcendental Thought: From Philip the Chancellor (ca. 1225) to Francisco Suárez, Brill, Leiden, 2012.

Aertsen, J., 'Why is Metaphysics Called 'First Philosophy' in the Middle Ages', u: G. T. Doolan (ed.), The Science of Being as Being. Metaphysical Investigation, The Catholic University of America Press, Washington, 2012.

Bertolacci, A., 'Avicenna's and Averroes's Interpretations and Their Influence in Albertus Magnus', u: F. Amerini, G. Galluzzo (eds.), A Companion to the Latin Medieval Commentaries on Aristotle's Metaphysics, Brill, Leiden, 2014.

Elders, L. J., The Metaphysics of Being of St. Thomas Aquinas in a Historical Perspective, Brill, Leiden, 1993.

Gilson, E., Thomism. The Philosophy of Thomas Aquinas, Pontifical Institute of Mediaeval Studies, Toronto, 2002.

Gracia, J. J. E., 'Categories vs. Genera: Suarez's Difficult Balancing Act', u: Medieval Metaphysics, or is it 'Just Semantics', Cambridge Scholars Publishing, Cambridge, 2011.

Hall, A. W., 'Confused Univocality', u: G. Klima, A. W. Hall (eds.), Medieval Metaphysics, or is it 'Just Semantics', Cambridge Scholars Publishing, Cambridge, 2011.

MacDonald, S., Being and Goodness: The Concept of the Good in Metaphysics and Philosophical Theology, Ithaca, Cornell University Press, 1991.

St. Thomas Aquinas, Questiones Disputatae De Veritate, Vol. I, Henry Regnery Company, Chicago, 1952.

St. Thomas Aquinas, Questiones Disputatae De Veritate, Vol. III, Henry Regnery Company, Chicago, 1954.

Wippel, J. F., Metaphysical Themes in Thomas Aquinas II, The Catholic University of America Press, Washington, D.C., 2007. 


\title{
UNA POPOVIĆ \\ University of Novi Sad, Faculty of Philosophy \\ THOMAS AQUINAS' DOCTRINE OF TRANSCENDENTALS: METAPHYSICS AND KNOWLEDGE
}

\begin{abstract}
Thomas Aquinas' doctrine of transcendentals is here presented with regard to its inherent epistemic character. The doctrine will be analyzed with respect to the general problem of the possibility of the transcendental concepts' development. The analysis results with the primacy of the secondary three transcendentals (aliquid, verum, bonum) as the key for the interpretation of the doctrine in general, as well as with the conclusion that the doctrine has a metaphysical, not theological character. Finally, the meaning of the doctrine of transcendentals is presented in the view of the development of the new Thomistic interpretation of metaphysics.
\end{abstract}

Keywords: transcendentals, Thomas Aquinas, metaphysics, knowledge, truth

Primljeno: 20.2.2019.

Prihvaćeno: 9.5.2019. 